\title{
Corrigendum: Mod-seq: high-throughput sequencing for chemical probing of RNA structure
}

\author{
JASON TALKISH, GEMMA MAY, YIZHU LIN, JOHN L. WOOLFORD JR., and C. JOEL MCMANUS
}

The authors would like to correct a recently identified typographical error in the Materials and Methods section of this manuscript. The sequence of the PCR primer listed as [5'-CAAGCAGAAGACGGCATACGAGAT-(6 nt barcode)TGTACTGGAGTTCAGACGTGTGCTCTTCCG-3'] is incorrect at the underlined bases and should be corrected to [5'-CAAGCAGAAGACGGCATACGAGAT-(6 nt barcode)-GTGACTGGAGTTCAGACGTGTGCTCTTCCG-3']. This has been corrected in the article online. The authors apologize for any inconvenience that may have resulted.

doi: $10.1261 /$ rna.072405.119

RNA 25: 840-856 (2019)

\section{Corrigendum: $\mathrm{ZC} 3 \mathrm{H} 12 \mathrm{~B} / \mathrm{MCPIP}$, a new active member of the $\mathrm{ZC} 3 \mathrm{H} 12$ family}

MATEUSZ WAWRO, KAROLINA WAWRO, JAKUB KOCHAN, ALEKSANDRA SOLECKA,
WERONIKA SOWINSKA, AGATA LICHAWSKA-CIESLAR, JOLANTA JURA, and ANETA KASZA

In the above-mentioned article, the affiliations included several inaccuracies and should read as follows:

${ }^{1}$ Department of Cell Biochemistry, ${ }^{2}$ Department of General Biochemistry, Faculty of Biochemistry, Biophysics and Biotechnology, Jagiellonian University, Krakow 30-387, Poland

This has been corrected online.

doi: $10.1261 /$ rna.072421.119 

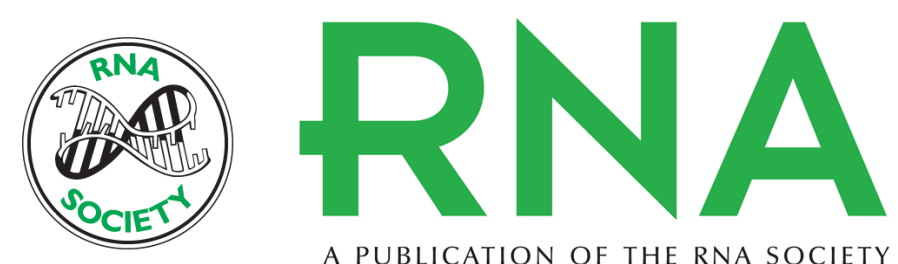

A PUBLICATION OF THE RNA SOCIETY

\section{Corrigendum: Mod-seq: high-throughput sequencing for chemical probing of RNA structure}

Jason Talkish, Gemma May, Yizhu Lin, et al.

RNA 2019 25: 1226_1

Related Content Mod-seq: high-throughput sequencing for chemical probing of RNA structure Jason Talkish, Gemma May, Yizhu Lin, et al.

RNA May , 2014 20: 713-720

Open Access Freely available online through the RNA Open Access option.

License

Email Alerting Receive free email alerts when new articles cite this article - sign up in the box at the Service top right corner of the article or click here.

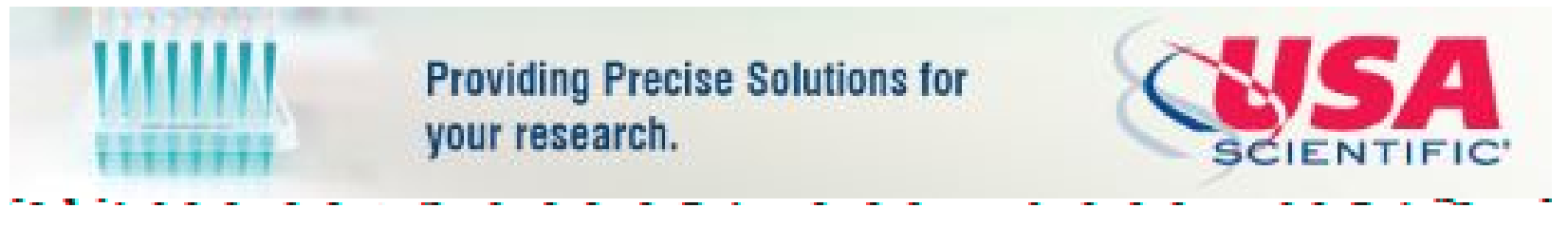

To subscribe to $R N A$ go to:

http://rnajournal.cshlp.org/subscriptions

Published by Cold Spring Harbor Laboratory Press for the RNA Society 